\title{
CONSERVATION AGRICULTURE PRACTICE AND ITS IMPACT ON FARMER'S LIVELIHOOD STATUS IN BANGLADESH
}

\author{
M. T. Uddin" and A. R. Dhar \\ Department of Agricultural Economics, Bangladesh Agricultural University \\ Mymensingh-2202, Bangladesh
}

\begin{abstract}
The study was conducted to assess the impact of conservation agriculture practice on livelihood status of farmers in Bangladesh. A total of 300 farmers (50 focal, 100 proximal and 150 control) from five districts (Mymensingh, Bogra, Tangail, Sherpur and Jamalpur) were selected. Focal farmers were selected purposively; and proximal and control farmers were selected randomly. Descriptive statistics like sum, averages, percentages and ratios were calculated to evaluate the socioeconomic data as well as to identify the nature and extent of conservation agriculture practiced. Expenditure elasticity measured the responsiveness of change in expenditure of the farmers with change in income. Difference-in-difference (DID) analysis and Ravallion test were done to evaluate the impact of conservation agriculture practice on farmers' income and expenditure. Multidimensional poverty index (MPI) was used to document the intensity of poverty. About 26.0, 25.0 and 18.6 percent focal, proximal and control farmers, respectively had basic knowledge about conservation agriculture practice; and 28.0, 19.0 and 15.3 percent, respectively received training on such practice. The adoption of different principles of conservation agriculture practice by focal farmers was satisfactory. The BCRs (Benefit cost ratio) for practicing conservation agriculture of focal, proximal and control farmers was $2.15,2.07$ and 1.92, respectively. The results of DID analysis and Ravallion test indicated that the impact of conservation agriculture practice on average annual income and expenditure of the farmers was statistically significant. The expenditure elasticity of focal, proximal and control farmers was $0.31,0.44$ and 0.58 percent, respectively. A remarkable improvement in farmers' livelihood status was found after adopting conservation agriculture practice. Input support, motivation, training programmes and extension services by different government and non-government organizations should be properly implemented to raise
\end{abstract}

\footnotetext{
* Corresponding author email: tajbau@ yahoo.com
}

Received: 13.05.2016 
the awareness and enrich the knowledge of the farmers on conservation agriculture practice.

Keywords: Conservation agriculture, farmers' livelihood, multidimensional poverty

\section{INTRODUCTION}

Agriculture is the heart of Bangladesh economy where more than $80 \%$ farmers are smallholder having land less than 1.0 hectare. The rural economy constitutes a significant component of the national GDP with agriculture accounting for $17.2 \%$ (BBS, 2014). In order to feed the increasing population of Bangladesh, 'Green Revolution' has emerged in 1960s and priority was given to produce more food through intensification of land usage (Akteruzzaman et al., 2012). As a result, Bangladesh had attained self sufficiency in food production for a shorter period. But long term use of chemical fertilizer and pesticides in conjunction with no use of any organic fertilizer resulted in lack of soil organic matter content. As a result, soil fertility and productivity is decreasing day by day (Kafiluddin and Islam, 2008). In this context, introduction of resource conserving agriculture is becoming increasingly important in overcoming the problems of declining agricultural productivity in a developing country like Bangladesh.

Conservation agriculture can be defined as a concept for resource-saving agricultural crop production that strives to achieve acceptable profits together with high and sustained production levels while concurrently conserving the environment (FAO, 2007). There are three key principles in the process of conservation agriculture; such as, continuous minimum mechanical soil disturbance; permanent organic soil cover; and diversified crop rotations. Conservation agriculture plays a vital role in increasing organic matter content in soil and in reducing soil erosion. Community based movement on conservation agriculture may contribute to livelihood and empowerment of communities (Rahman, 2001). Although this farming aims to help farmers to earn more income with reduced amount of labour, irrigation and other high energy external input costs; keep land healthy and productive; and conserve natural environment (Lampkin and Padel, 1994); about 8-10\% farmers around the world follow this practice (Parrott et al., 2006; Willer et al., 2008).

The reality for many smallholder farmers is that their soils have become severely depleted through generations of unsustainable farming methods including ploughing, monocropping, little or no replenishment of nutrients and burning of residues. Ultimately, such practices result in decreased yields. Conservation agriculture has a positive impact on farmers' livelihood having potential to turn around the daily and seasonal calendar; and change the rhythm of farmers' livelihood. The labour input in this system could be reduced by 75\% (IFAD, 2005 and FAO, 2007). The time saved under conservation agriculture allows farmers to dedicate more time to other more profitable non-farm occupations for generating 
income than growing a crop. More time availability offers real opportunities for diversification options. For women, conservation agriculture provides opportunities to engage themselves in other income generating and socioeconomic activities while also sparing more time to take care of the family.

Modalities of such farming have been described in a good number of literatures in the global context as well as in the context of Bangladesh. A modest attempt has been made here to review the previous research studies which are: Akter and Gathala (2014) conducted a research on adoption of conservation agriculture technology in diversified systems and impact on productivity in Bangladesh; and revealed that diversities existed between locations, cropping systems and seasons affected intensity of adoption. Nkala (2012) assessed the impacts of conservation agriculture on farmers' livelihood in Central Mozambique and discovered that under the conditions of vulnerable livelihood, lack of access to agricultural assets, lack of institutions supporting smallholder farmers, conservation agriculture had only a weak impact on livelihood outcomes, mostly through a slight improvement in crop productivity. Tshuma et al. (2012) assessed the impact of conservation agriculture on food security and livelihood in Zimbabwe and found that conservation agriculture extended the range of livelihood on a limited scale, through improved yields and income.

The literature reviews mentioned above indicate that most of the studies dealt with livelihood outcome through practicing conservation agriculture though these are not relating to Bangladesh. Therefore, to minimize the research gap, this study would be helpful at examining the socioeconomic issues on improving livelihood status of farmers through adoption of conservation agriculture in Bangladesh. The overall goal of the present study is to evaluate the impact of conservation agriculture practice on farmers' livelihood improvement in Bangladesh. The specific objectives are: i) to assess the nature and extent of conservation agriculture practiced and ii) to evaluate the impact of conservation agriculture practice to improve the farmers' livelihood status.

\section{MATERIALS AND METHODS}

The study was conducted in five agro-ecological zones of Bangladesh where the movement for practicing conservation agriculture are getting interest among farmers for several years. The considered districts were Mymensingh (major crop: potato), Bogra (major crop: bean), Tangail (major crop: pineapple), Sherpur (major crop: rice) and Jamalpur (major crop: wheat). Three categories of farmers were targeted for investigation namely, focal farmers (farmers receiving technical and logistic support for practicing conservation agriculture from the project and having regular contact with extension support staff), proximal farmers (neighboring of focal farmers receiving indirect support like technical advice and having occasional contact with the extension staff) and control farmers (who are receiving no training and technical support on conservation agriculture from any organization and also from 
the project staff). In each locale of the study, a total of 60 farmers (10 focal, 20 proximal and 30 control) were selected; of which focal farmers were selected purposively, and proximal and control farmers were selected randomly. Thus, a total of 300 farmers were included as the sample for observation and data collection. Primary data were collected through questionnaire survey, focus group discussion (FGD) and key informant interview (KII) with local stakeholders. Secondary sources of data in the form of handouts, reports, publications, notifications, etc. having relevance with this study were also consulted.

\section{Model specification}

An amalgamation of descriptive statistics, mathematical and statistical techniques was used to achieve the objectives of the study. Descriptive statistics like sum, averages and percentages were calculated to assess the socioeconomic characteristics of the sample farmers, and identify the nature and extent of conservation agriculture practiced. For evaluating the impact of adopting conservation agriculture practice on farmers' livelihood, expenditure elasticity, difference-in-difference (DID) analysis, Ravallion test and multidimensional poverty index (MPI) were used.

\section{Difference-in-difference (DID) analysis}

DID analysis is necessary to construct a counterfactual measure of what would have happened if the intervention had not been available, and to find the difference between the previous and present situation after the intervention. The following formula was used for estimating difference-in-differences:

$\mathrm{DID}_{\mathrm{FP}}=\left(\mathrm{F}_{1}-\mathrm{P}_{1}\right)-\left(\mathrm{F}_{0}-\mathrm{P}_{0}\right)$

Where,

$\mathrm{F}_{0}=$ 'Before' situation of focal farmers adopting conservation agriculture practice;

$\mathrm{F}_{1}=$ 'After' situation of focal farmers adopting conservation agriculture practice;

$\mathrm{P}_{0}=$ 'Before' situation of proximal farmers adopting conservation agriculture practice; and

$\mathrm{P}_{1}=$ 'After' situation of proximal farmers adopting conservation agriculture practice.

$\mathrm{DID}_{\mathrm{FC}}=\left(\mathrm{F}_{1}-\mathrm{C}_{1}\right)-\left(\mathrm{F}_{0}-\mathrm{C}_{0}\right)$

Where,

$\mathrm{F}_{0}=$ 'Before' situation of focal farmers adopting conservation agriculture practice;

$\mathrm{F}_{1}=$ 'After' situation of focal farmers adopting conservation agriculture practice; 
$\mathrm{C}_{0}=$ 'Before' situation of control farmers adopting conservation agriculture practice; and

$\mathrm{C}_{1}=$ 'After' situation of control farmers adopting conservation agriculture practice.

$\mathrm{DID}_{\mathrm{PC}}=\left(\mathrm{P}_{1}-\mathrm{C}_{1}\right)-\left(\mathrm{P}_{0}-\mathrm{C}_{0}\right)$

Where,

$\mathrm{P}_{0}=$ 'Before' situation of proximal farmers adopting conservation agriculture practice;

$\mathrm{P}_{1}=$ 'After' situation of proximal farmers adopting conservation agriculture practice;

$\mathrm{C}_{0}=$ 'Before' situation of control farmers adopting conservation agriculture practice; and

$\mathrm{C}_{1}=$ 'After' situation of control farmers adopting conservation agriculture practice.

\section{Ravallion test}

The impacts of adopting conservation agriculture practice were measured by using comparison of focal, proximal and control farmers' income, expenditure and savings with the help of Ravallion test. The formula used for estimation defined by Ravallion (2008) was as follows:

$\mathrm{I}_{\mathrm{FP}}=\frac{1}{\mathrm{n}} \sum_{\mathrm{i}=1}^{\mathrm{n}}\left(\mathrm{O}_{\mathrm{i}}^{\mathrm{F}}-\mathrm{O}_{\mathrm{i}}^{\mathrm{P}}\right)$

Where,

$\mathrm{I}=$ Average impact of conservation agriculture practice;

$\mathrm{O}=$ Value of interpretable impact indicator; $\mathrm{F}=$ Focal farmers;

$\mathrm{P}=$ Proximal farmers $; \mathrm{i}=$ Sample units; and $\mathrm{n}=$ Sample size .

$\mathrm{I}_{\mathrm{FC}}=\frac{1}{\mathrm{n}} \sum_{\mathrm{i}=1}^{\mathrm{n}}\left(\mathrm{O}_{\mathrm{i}}^{\mathrm{F}}-\mathrm{O}_{\mathrm{i}}^{\mathrm{C}}\right)$

Where,

$\mathrm{I}=$ Average impact of conservation agriculture practice;

$\mathrm{O}=$ Value of interpretable impact indicator; $\mathrm{F}=$ Focal farmers;

$\mathrm{C}=$ Control farmers; $\mathrm{i}=$ Sample units; and $\mathrm{n}=$ Sample size .

$\mathrm{I}_{\mathrm{PC}}=\frac{1}{\mathrm{n}} \sum_{\mathrm{i}=1}^{\mathrm{n}}\left(\mathrm{O}_{\mathrm{i}}^{\mathrm{P}}-\mathrm{O}_{\mathrm{i}}^{\mathrm{C}}\right)$ 
Where,

$I=$ Average impact of conservation agriculture practice;

$\mathrm{O}=$ Value of interpretable impact indicator; $\mathrm{P}=$ Proximal farmers;

$\mathrm{C}=$ Control farmers $; \mathrm{i}=$ Sample units; and $\mathrm{n}=$ Sample size.

\section{Expenditure elasticity}

Expenditure elasticity is a measure of the responsiveness of expenditure on, or consumption of, a good to a change in real income, when other factors remain the same, and where expenditure is a proxy for income (Browne et al., 2007). Expenditure elasticity of the farmers was calculated using the following formula:

$\mathrm{E}_{\mathrm{F}}=\left(\partial \mathrm{Y}_{\mathrm{F}} \div \partial \mathrm{I}_{\mathrm{F}}\right) \times\left(\mathrm{I}_{\mathrm{F}} \div \mathrm{Y}_{\mathrm{F}}\right)$

Where,

$\mathrm{E}_{\mathrm{F}}=$ Expenditure elasticity of focal farmers;

$\partial \mathrm{Y}_{\mathrm{F}}=$ Change in expenditure of focal farmers;

$\partial \mathrm{I}_{\mathrm{F}}=$ Change in income of focal farmers;

$\mathrm{Y}_{\mathrm{F}}=$ Expenditure of focal farmers before practicing conservation agriculture; and agriculture.

$\mathrm{I}_{\mathrm{F}}=$ Income of focal farmers before practicing conservation

$$
\mathrm{E}_{\mathrm{P}}=\left(\partial \mathrm{Y}_{\mathrm{P}} \div \partial \mathrm{I}_{\mathrm{P}}\right) \times\left(\mathrm{I}_{\mathrm{P}} \div \mathrm{Y}_{\mathrm{P}}\right)
$$

Where,

$\mathrm{E}_{\mathrm{P}}=$ Expenditure elasticity of proximal farmers;

$\partial \mathrm{Y}_{\mathrm{P}}=$ Change in expenditure of proximal farmers;

$\partial \mathrm{I}_{\mathrm{P}}=$ Change in income of proximal farmers;

$Y_{P}=$ Expenditure of proximal farmers before practicing conservation

agriculture; and

agriculture.

$I_{P}=$ Income of proximal farmers before practicing conservation

$$
\mathrm{E}_{\mathrm{C}}=\left(\partial \mathrm{Y}_{\mathrm{C}} \div \partial \mathrm{I}_{\mathrm{C}}\right) \times\left(\mathrm{I}_{\mathrm{C}} \div \mathrm{Y}_{\mathrm{C}}\right)
$$

Where,

agriculture;

$\mathrm{E}_{\mathrm{C}}=$ Expenditure elasticity of control farmers;

$\partial \mathrm{Y}_{\mathrm{C}}=$ Change in expenditure of control farmers;

$\partial \mathrm{I}_{\mathrm{C}}=$ Change in income of control farmers;

$\mathrm{Y}_{\mathrm{C}}=$ Expenditure of control farmers before practicing conservation and 
agriculture.

$$
\mathrm{I}_{\mathrm{C}}=\text { Income of control farmers before practicing conservation }
$$

\section{Multidimensional poverty index (MPI)}

The MPI is an index designed to measure the intensity of poverty (HDR, 2015). It comprises three equally weighted poverty dimensions; health, education and living standards. The health dimension is measured by the two equally weighted indicators, nutrition and child mortality. Education is captured by the two equally weighted indicators, years of schooling and child enrolment. Living standards are measured by the six equally weighted indicators; cooking fuel, sanitation, water, electricity, floor and assets. The following formula was used to appraise the intensity of poverty:

Intensity of poverty $=[\{\Sigma \mathrm{c}(\mathrm{k})\} \div \Sigma \mathrm{q}] \times 100$

Where,

$$
\begin{aligned}
& \mathrm{c}=\text { Households deprived of the indicators; } \\
& \mathrm{k}=\text { Weighted score of the indicators } \text { and } \\
& \mathrm{q}=\text { Average household size in each area. }
\end{aligned}
$$

\section{RESULTS AND DISCUSSION}

\section{Profile of the selected farmers}

Table 1 represents the basic information of the selected farmers in the study areas. It is found that average household and farm size of focal, proximal and control farmers was 6.0, 5.0 and 6.0; and $0.44,0.46$ and 0.45 respectively. Average dependency ratio of focal farmers (1.5) was comparatively lower than proximal and control farmers (1.7 and 3.0, respectively) which indicate that focal farmers were more self-sufficient and self-employed. The percentages of male and female respondents were 68.0, 69.5 and 69.2; and 32.0, 30.5 and 30.8 for focal, proximal and control farmers, respectively. Average age of focal, proximal and control farmers was 31,38 and 36 years, respectively. Though 42.0 percent focal farmers could put sign only, majority of the proximal and control farmers (56.5 and 55.6 percent, respectively) were illiterate in the study areas. Most of the farmers were engaged in agriculture as well as other income generating activities like labour selling, service, small business, etc. (76.0 percent for both focal and proximal farmers and 70.8 percent control farmers). It is also shown that majority of the farmers were commercial farmers $(82.0,70.5$ and 76.0 percent focal, proximal and control farmers, respectively) in the study areas (Table 1 ). 
Table 1. Basic information about the selected farmers

\begin{tabular}{ll|c|c|c}
\hline \multirow{2}{*}{ Particulars } & \multicolumn{3}{c}{ Farmers' categories } \\
\cline { 3 - 5 } & & Focal & Proximal & Control \\
\hline Average household size (no.) & 6 & 5 & 6 \\
Average farm size (ha) & & 0.44 & 0.46 & 0.45 \\
Average dependency ratio (no.) & 1.5 & 1.7 & 3.0 \\
Average sex distribution & Male & 68.0 & 69.5 & 69.2 \\
(\% of farmers) & Female & 32.0 & 30.5 & 30.8 \\
Average age (years) & & 31 & 38 & 36 \\
& Illiterate & 32.0 & 56.5 & 55.6 \\
Literacy rate & Sign only & 42.0 & 27.5 & 22.4 \\
(\% of farmers) & Primary and above & 26.0 & 16.0 & 22.0 \\
Occupational status & Agriculture only & 24.0 & 24.0 & 29.2 \\
(\% of farmers) & Agriculture and others & 76.0 & 76.0 & 70.8 \\
Farming systems practiced & Subsistence & 18.0 & 29.5 & 24.0 \\
(\% of farmers) & Commercial & 82.0 & 70.5 & 76.0 \\
\hline
\end{tabular}

Source: Field survey, 2015-16.

\section{Extent of farmers' knowledge about conservation agriculture practice}

Table 2 represents the extent of basic knowledge about conservation agriculture practice and training received by the farmers on crop cultivation in the study areas. It is seen that 26.0, 25.0 and 18.6 percent focal, proximal and control farmers, respectively had fundamental knowledge about conservation agriculture practice. Also, 28.0, 19.0 and 15.3 percent focal, proximal and control farmers, respectively received training on crop farming in the study areas.

Table 2. Extent of farmers' knowledge about conservation agriculture practice (in percentages of farmers)

\begin{tabular}{l|c|c|c}
\hline \multirow{2}{*}{ Particulars } & \multicolumn{3}{|c}{ Farmers' categories } \\
\cline { 2 - 4 } & $\begin{array}{c}\text { Focal } \\
(\mathrm{n}=50)\end{array}$ & $\begin{array}{c}\text { Proximal } \\
(\mathrm{n}=100)\end{array}$ & $\begin{array}{c}\text { Control } \\
(\mathrm{n}=150)\end{array}$ \\
\hline Zero/minimum tillage & 6.0 & 7.0 & 5.3 \\
Crop residue management & 12.0 & 12.0 & 7.3 \\
Diversified crop rotation & 8.0 & 6.0 & 6.0 \\
Total & 26.0 & 25.0 & 18.6 \\
Training received on crop farming & 28.0 & 19.0 & 15.3 \\
\hline
\end{tabular}

Source: Field survey, 2015-16. 


\section{Sources of knowledge and purposes of training provided}

Generally, the farmers of the study areas gathered knowledge about conservation agriculture practice from different government and non-government organizations such as BAUEC, CVDCL, CGUS, DAE, Caritas Bangladesh and CIMMYT. Farmers had been given knowledge and training on organic farming, mixed cropping, assessment of climate change impact, improvement of soil quality, IPM Technology, formalin free fruit production, etc. (Table 3).

Table 3. Sources of knowledge and issues on training provided

\begin{tabular}{|c|c|c|c|}
\hline Study areas & Institutions & $\begin{array}{l}\text { Duration } \\
\text { (days) }\end{array}$ & Purposes \\
\hline Mymensingh & BAUEC & 03 & $\begin{array}{l}\text { Preparation of vermicompost, } \\
\text { improvement of soil quality, using IPM } \\
\text { Technology. }\end{array}$ \\
\hline Bogra & $\begin{array}{l}\text { CVDCL and CGUS } \\
\text { : Local NGOs }\end{array}$ & 07 & $\begin{array}{l}\text { Organic farming, using cowdung instead } \\
\text { of synthetic fertilizer. }\end{array}$ \\
\hline Tangail & DAE & 02 & $\begin{array}{l}\text { Formalin free pineapple production, } \\
\text { mixed cropping. }\end{array}$ \\
\hline Sherpur & Caritas Bangladesh & 05 & $\begin{array}{l}\text { Soil quality improvement, promoting } \\
\text { safe drinking water, impact of climate } \\
\text { change assessment. }\end{array}$ \\
\hline Jamalpur & CIMMYT & 03 & $\begin{array}{l}\text { Crop residue practicing, using cowdung, } \\
\text { dhaincha cultivation for increasing } \\
\text { nitrogen in the soil. }\end{array}$ \\
\hline
\end{tabular}

Source: Field survey, 2015-16.

\section{Nature of adopting conservation agriculture practice}

Before adopting conservation agriculture practice, the farmers of each category in the study areas were fully dependent on synthetic fertilizers, pesticides and medicines in some cases. After adopting conservation agriculture practice, focal farmers followed the basic principles of conservation agriculture. Proximal farmers observed the farming practices of focal farmers' and tried to follow them, but control farmers did not follow any principle of conservation agriculture practice rather they continued traditional crop farming practices. Table 4 shows the nature of adopting conservation agriculture practice by the farmers in the study areas. 
Table 4. Nature of conservation agriculture practice adopted by the farmers

\begin{tabular}{|c|c|c|c|}
\hline \multirow{2}{*}{ Particulars } & \multicolumn{3}{|c|}{ Farmers' categories } \\
\hline & Focal & Proximal & Control \\
\hline Practicing zero/ minimum tillage & $\sqrt{ }$ & $x$ & $x$ \\
\hline Retaining crop residue & $\sqrt{ }$ & $\sqrt{ }$ & $x$ \\
\hline Practicing crop rotation & ए & $x$ & $x$ \\
\hline Using synthetic fertilizers & ๘ & ๘ & $\sqrt{ }$ \\
\hline Using synthetic pesticides & $x$ & ه & $\sqrt{ }$ \\
\hline Using herbicides & $x$ & ए & $\sqrt{ }$ \\
\hline Using medicine & $x$ & $x$ & $\sqrt{ }$ \\
\hline Using compost & $\sqrt{ }$ & $\sqrt{ }$ & $x$ \\
\hline Using vermicompost & $\sqrt{ }$ & $x$ & $x$ \\
\hline Using cowdung & $\sqrt{ }$ & $\sqrt{ }$ & 『 \\
\hline Using bioslurry & $\sqrt{ }$ & $\sqrt{ }$ & Ф \\
\hline Using IPM technology & $\sqrt{ }$ & $x$ & $x$ \\
\hline
\end{tabular}

Source: Field survey, 2015-16.

Note: $\sqrt{ }$, $\bowtie$ and $\times$ indicate full, partial and no adoption, respectively.

It is experienced that focal farmers of the research areas fully adopted practicing zero/minimum tillage and retaining crop residue. As the selection of appropriate crop rotation is a lengthy process, it was partially adopted by them. It was not possible for them to diminish the use of synthetic fertilizers fully, but the full use of organic fertilizers (compost, vermicompost, cowdung and bioslurry) and IPM technology; and no use of pesticides, herbicides and medicines were ensured. In case of proximal farmers, full adoption was experienced only in terms of retaining crop residue, and using compost, cowdung and bioslurry. They adopted partial use of fertilizers, pesticides and herbicides. On the other hand, no control farmer practiced zero/minimum tillage, retained crop residue or practiced appropriate crop rotation. They continued full use of synthetic fertilizers, pesticides, herbicides and medicines; and partial use of cowdung and bioslurry.

\section{Profitability of crop farming}

Profitability of crop farming from the view point of individual farmers was measured in terms of gross return, gross margin, net return and benefit cost ratio (undiscounted). For calculating the total production cost, variable and fixed costs were taken into consideration. The components of variable costs were: i) human 
labour, ii) power tiller cost, iii) seeds/seedlings, iv) fertilizers, v) pesticides, vi) medicine, vii) irrigation and viii) fencing.

Focal farmers were provided input support with 10.0 decimal land for practicing conservation agriculture. It is evident from table 5 that after adopting conservation agriculture practice, total cost per 10 decimal land was decreased to Tk. 6056, Tk. 6149 and Tk. 6360 where these were Tk. 6396, Tk. 6375 and Tk. 6413 for focal, proximal and control farmers, respectively before adopting conservation agriculture practice. Gross and net return were increased to Tk. 13004, Tk. 12755 and Tk. 12225; and Tk. 6949, Tk. 6606 and Tk. 5865 in case of focal, proximal and control farmers, respectively after adopting conservation agriculture practice. BCR of focal, proximal and control farmers was $1.95,1.95$ and 1.89 , respectively before adopting conservation agriculture practice but after adopting conservation agriculture practice, it was increased to $2.15,2.07$ and 1.92, respectively.

Table 5. Profitability analysis of crop production

\begin{tabular}{l|c|c|c|c}
\hline \multicolumn{4}{c}{ Profitability of crop production per 10.0 decimal land } \\
\hline \multirow{2}{*}{ Particulars } & & \multicolumn{3}{c}{ Farmers' categories } \\
\cline { 3 - 5 } Total cost & Before (Tk.) & 6396 & 6375 & 6413 \\
& After (Tk.) & 6056 & 6149 & 6360 \\
Gross return & Before (Tk.) & 12459 & 12410 & 12140 \\
& After (Tk.) & 13004 & 12755 & 12225 \\
Net return & Before (Tk.) & 6063 & 6035 & 5727 \\
Benefit cost ratio & After (Tk.) & 6949 & 6606 & 5865 \\
(BCR) & Before & 1.95 & 1.95 & 1.89 \\
Total cost & After & 2.15 & 2.07 & 1.92 \\
\multirow{3}{*}{ Gross return } & Before (Tk.) & 71088 & 70859 & 71280 \\
& After (Tk.) & 67311 & 68351 & 70695 \\
Net return & Before (Tk.) & 138480 & 137941 & 134933 \\
Benefit cost ratio & After (Tk.) & 144545 & 141772 & 135886 \\
(BCR) & Before (Tk.) & 67392 & 67082 & 63653 \\
\hline
\end{tabular}

Source: Authors' estimation, 2015-16. 
Performing the sensitivity analysis, the profitability analysis of crop produced per 10 decimal land was converted into per 0.45 ha land (average farm size of the three categories of farmers) to check whether the intervention would beneficial to the farmers if they used conservation agriculture practice to their entire cropland. It is seen from table 5 that total cost per hectare would decrease to Tk. 67311, Tk. 68351 and Tk. 70695 from Tk. 71088, Tk. 70859 and Tk. 71280 in case of focal, proximal and control farmers, respectively. Reduction in labour and fertilizer cost was the major reason for declining in total cost. Gross return of focal, proximal and control farmers would increase from Tk. 138480, Tk. 137941 and Tk. 134933, respectively to Tk. 144545, Tk. 141772 and Tk. 135886, respectively; and therefore, net return would increase to Tk. 77234, Tk. 73420 and Tk. 65191, respectively from Tk. 67392, Tk. 67082 and Tk. 63653, respectively. BCR of focal, proximal and control farmers would remain the same as calculated per 10 decimal land which clearly indicated that crop production was more profitable in the study areas after adopting conservation agriculture practice (Table 5). High market demand of organic and fertilizer free products forced to increase in per unit price of output in the market was the major reason of increasing the revenue of the farmers in the study areas. The result of the study is a little bit similar with Dhaliwal and Singh (2004) where the authors observed a significant decline in the cost of crop production due to less use of farm machinery, labour and agro-chemicals; and higher yield due to less lodging of crop.

\section{Average annual income of the sample farmers}

Table 6 represents the money income earned by the farmers from different sources in the study areas. Mainly, there were two sources of income: farm income and non-farm income. Farm income included income from different agricultural enterprises like crop (rice, vegetables, etc.), livestock (large animal i.e., cow, ox, bullock, buffalo, goat, sheep, etc.; and small animal i.e., poultry, duck, pigeon, etc.), fishery, agroforestry and others. Non-farm income included income from other income generating activities except agriculture like small business, wage labour, shopkeeping and others. It is apparent that average annual farm income of focal, proximal and control farmers was increased by 9.3, 7.2 and 6.2 percent, respectively; and average annual non-farm income increased by $10.1,7.9$ and 5.4 percent, respectively. Overall, average annual income of focal, proximal and control farmers increased by 9.6, 7.4 and 6.0 percent, respectively (Table 7). The results imply that while before practicing conservation agriculture farmers earned Tk. 100 money income, after practicing conservation agriculture focal, proximal and control farmers earned about Tk. 110, Tk. 107 and Tk. 106 money income, respectively. Farmers adopting conservation agriculture practice could save more time and money to invest in other income generating activities compared to who are not adopting which ultimately resulted in more money income in case of focal farmers in comparison with proximal and control farmers. 
Table 6. Average annual income of the farmers

\begin{tabular}{|c|c|c|c|c|c|c|c|c|c|c|}
\hline \multirow{3}{*}{\multicolumn{2}{|c|}{ Sources of income }} & \multicolumn{9}{|c|}{ Farmers' categories } \\
\hline & & \multicolumn{3}{|c|}{ Focal } & \multicolumn{3}{|c|}{ Proximal } & \multicolumn{3}{|c|}{ Control } \\
\hline & & \begin{tabular}{|c|} 
Before \\
(Tk.)
\end{tabular} & $\begin{array}{l}\text { After } \\
\text { (Tk.) }\end{array}$ & $\begin{array}{c}\begin{array}{c}\text { Change } \\
(\%)\end{array} \\
\end{array}$ & $\begin{array}{c}\text { Before } \\
\text { (Tk.) }\end{array}$ & $\begin{array}{l}\text { After } \\
\text { (Tk.) }\end{array}$ & $\begin{array}{c}\text { Change } \\
(\%)\end{array}$ & $\begin{array}{c}\text { Before } \\
\text { (Tk.) }\end{array}$ & $\begin{array}{l}\text { After } \\
\text { (Tk.) }\end{array}$ & $\begin{array}{c}\text { Change } \\
(\%)\end{array}$ \\
\hline \multirow{7}{*}{$\begin{array}{l}\text { Farm } \\
\text { income }\end{array}$} & Rice & 28053 & 30196 & 7.6 & 28301 & 30121 & 6.4 & 28379 & 30033 & 5.8 \\
\hline & Vegetables & 33220 & 36406 & 9.6 & 32365 & 34726 & 7.3 & 32992 & 35132 & 6.5 \\
\hline & Fruits & 8602 & 9095 & 5.7 & 8759 & 9107 & 4.0 & 8621 & 8933 & 3.6 \\
\hline & Agroforestry & 1675 & 2043 & 22.0 & 1786 & 1995 & 11.7 & 1784 & 1938 & 8.6 \\
\hline & Livestock & 8154 & 9285 & 13.9 & 8797 & 9672 & 9.9 & 9132 & 9855 & 7.9 \\
\hline & Fisheries & 700 & 850 & 21.4 & 624 & 793 & 27.1 & 691 & 817 & 18.2 \\
\hline & Others & 1859 & 2070 & 11.4 & 1852 & 2023 & 9.2 & 1940 & 2047 & 5.5 \\
\hline \multicolumn{2}{|c|}{ Total farm income } & 82263 & 89945 & 9.3 & 82484 & 88437 & 7.2 & 83539 & 88755 & 6.2 \\
\hline \multirow{4}{*}{$\begin{array}{l}\text { Non- } \\
\text { farm } \\
\text { income }\end{array}$} & $\begin{array}{l}\text { Small } \\
\text { business }\end{array}$ & 15611 & 17397 & 11.4 & 15667 & 17355 & 10.8 & 15609 & 16572 & 6.2 \\
\hline & Wage labour & 10318 & 10702 & 3.7 & 10098 & 10528 & 4.3 & 10356 & 10708 & 3.4 \\
\hline & Shopkeeping & 4500 & 4600 & 2.2 & 4633 & 4692 & 1.3 & 4396 & 4463 & 1.5 \\
\hline & Others & 7854 & 9458 & 20.4 & 8377 & 9271 & 10.7 & 8212 & 8913 & 8.5 \\
\hline \multicolumn{2}{|c|}{$\begin{array}{l}\text { Total non-farm } \\
\text { income }\end{array}$} & 38282 & 42157 & 10.1 & 38775 & 41846 & 7.9 & 38573 & 40655 & 5.4 \\
\hline \multicolumn{2}{|c|}{ Total income } & 120545 & 132102 & 9.6 & 121259 & 130283 & 7.4 & 122112 & 129410 & 6.0 \\
\hline
\end{tabular}

Source: Authors' estimation, 2015-16.

\section{Average annual expenditure of the sample farmers}

Average annual expenditure of the farmers in the study areas is revealed in table 7. The major sectors of farmers' expenditure identified were food, clothes, health services, house repairing, education, electricity/fuel, transportation, festivals and miscellaneous items. The highest portion of farmers' expenditure included food consumption followed by expenditure on festivals and miscellaneous items. It is found from table 7 that the rate of increase in average annual expenditure of focal, proximal and control farmers was more or less similar $(2.8,3.0$ and 3.2 percent, respectively). The results entail that before adopting conservation agriculture practice farmers' expenditure was Tk. 100, and after adopting conservation agriculture focal, proximal and control farmers' expenditure were Tk. 102.8, Tk. 103 and Tk. 103.2, respectively. In case of focal farmers, the cost of labour and input expense decreased due to minimum tillage and less use of synthetic fertilizers; and, therefore, the average annual expenditure of focal farmers was comparatively lower than proximal and control farmers. 
Table 7. Average annual expenditure of the farmers

\begin{tabular}{|c|c|c|c|c|c|c|c|c|c|}
\hline \multirow{3}{*}{ Particulars } & \multicolumn{9}{|c|}{ Farmers' categories } \\
\hline & \multicolumn{3}{|c|}{ Focal } & \multicolumn{3}{|c|}{ Proximal } & \multicolumn{3}{|c|}{ Control } \\
\hline & $\begin{array}{l}\text { Before } \\
\text { (Tk.) }\end{array}$ & $\begin{array}{l}\text { After } \\
\text { (Tk.) }\end{array}$ & $\begin{array}{c}\text { Change } \\
(\%)\end{array}$ & $\begin{array}{c}\text { Before } \\
\text { (Tk.) }\end{array}$ & $\begin{array}{l}\text { After } \\
\text { (Tk.) }\end{array}$ & $\begin{array}{c}\text { Change } \\
(\%)\end{array}$ & $\begin{array}{c}\text { Before } \\
\text { (Tk.) }\end{array}$ & $\begin{array}{l}\text { After } \\
\text { (Tk.) }\end{array}$ & $\begin{array}{c}\text { Change } \\
(\%)\end{array}$ \\
\hline Food & 54908 & 56095 & 2.2 & 54965 & 55897 & 1.7 & 54936 & 56079 & 2.1 \\
\hline Clothes & 7041 & 7293 & 3.6 & 7005 & 7210 & 2.9 & 7080 & 7356 & 3.9 \\
\hline Health services & 2696 & 2810 & 4.2 & 2812 & 2935 & 4.4 & 2886 & 3034 & 5.1 \\
\hline House repairing & 3084 & 3207 & 4.0 & 3195 & 3335 & 4.4 & 3126 & 3262 & 4.3 \\
\hline Education & 3155 & 3253 & 3.1 & 3078 & 3173 & 3.1 & 3126 & 3213 & 2.8 \\
\hline Electricity/fuel & 3206 & 3333 & 4.0 & 3330 & 3504 & 5.2 & 3411 & 3575 & 4.8 \\
\hline Transportation & 2468 & 2617 & 6.0 & 2805 & 2983 & 6.3 & 2798 & 2932 & 4.8 \\
\hline Festivals & 14281 & 15086 & 5.6 & 14637 & 15516 & 6.0 & 14863 & 15672 & 5.4 \\
\hline Miscellaneous & 20767 & 21089 & 1.6 & 20624 & 21241 & 3.0 & 20942 & 21614 & 3.2 \\
\hline $\begin{array}{l}\text { Total } \\
\text { expenditure }\end{array}$ & 111606 & 114782 & 2.8 & 112451 & 115794 & 3.0 & 113168 & 116737 & 3.2 \\
\hline
\end{tabular}

Source: Authors' estimation, 2015-16.

\section{Difference-in-difference (DID) analysis}

DID analysis was used to document the impact of conservation agriculture practice on farmers' average annual income and expenditure in case of both 'before' and 'after' adoption; and 'with' and 'without' adoption within focal, proximal and control farmers. Table 8 represents the results of DID analysis for average annual income and expenditure of the farmers in the study areas. It is seen that within focal and proximal farmers, the DID estimated value of average annual farm income, nonfarm income, total income and total expenditure was Tk. 1729, Tk. 804, Tk. 2533 and Tk. 167, respectively; within focal and control farmers it was Tk. 2466, Tk. 1793, Tk. 4259 and Tk. 393, respectively; and within proximal and control farmers it was Tk. 737, Tk. 989, Tk. 1726 and Tk. 226, respectively. The negative sign in case of average annual expenditure indicates 'decreased' situation. In most of the cases, a positive and statistically significant change is occurred which brings an indication that adoption of conservation agriculture practice had a significant impact on average annual income and expenditure of the farmers in the study areas. The result is slightly supported by Kumar et al. (2011) where the authors identified significant economic benefits in terms of income and wealth generation from a variety of conservation agriculture practices. 
Table 8. Estimation of DID analysis to evaluate impact on average annual income and expenditure of the farmers

\begin{tabular}{|c|c|c|c|c|}
\hline \multicolumn{5}{|c|}{ For focal and proximal farmers } \\
\hline \multirow{2}{*}{ Particulars } & & \multicolumn{2}{|c|}{ Farmers' categories } & \multirow{2}{*}{ Difference } \\
\hline & & Focal & Proximal & \\
\hline \multirow{3}{*}{ Farm income } & Before (Tk.) & 82263 & 82484 & -221 \\
\hline & After (Tk.) & 89945 & 88437 & 1508 \\
\hline & Difference (Tk.) & 7682 & 5953 & $1729(0.0095 * * *)$ \\
\hline \multirow{3}{*}{ Non-farm income } & Before (Tk.) & 38282 & 38775 & -493 \\
\hline & After (Tk.) & 42157 & 41846 & 311 \\
\hline & Difference (Tk.) & 3875 & 3071 & $804(0.1285)$ \\
\hline \multirow{3}{*}{ Total income } & Before (Tk.) & 120545 & 121259 & -714 \\
\hline & After (Tk.) & 132102 & 130283 & 1819 \\
\hline & Difference (Tk.) & 11557 & 9024 & $2533\left(0.0936^{*}\right)$ \\
\hline \multirow{3}{*}{ Total expenditure } & Before (Tk.) & 111606 & 112451 & -845 \\
\hline & After (Tk.) & 114782 & 115794 & -1012 \\
\hline & Difference (Tk.) & 3176 & 3343 & $-167(0.1428)$ \\
\hline \multirow{3}{*}{ Farm income } & Before (Tk.) & 82263 & 83539 & -1276 \\
\hline & After (Tk.) & 89945 & 88755 & 1190 \\
\hline & Difference (Tk.) & 7682 & 5216 & $2466(0.4316)$ \\
\hline \multirow{3}{*}{ Non-farm income } & Before (Tk.) & 38282 & 38573 & -291 \\
\hline & After (Tk.) & 42157 & 40655 & 1502 \\
\hline & Difference (Tk.) & 3875 & 2082 & $1793(0.0820 *)$ \\
\hline \multirow{3}{*}{ Total income } & Before (Tk.) & 120545 & 122112 & -1567 \\
\hline & After (Tk.) & 132102 & 129410 & 2692 \\
\hline & Difference (Tk.) & 11557 & 7298 & $4259(0.0024 * * *)$ \\
\hline \multirow{3}{*}{ Total expenditure } & Before (Tk.) & 111606 & 113168 & -1562 \\
\hline & After (Tk.) & 114782 & 116737 & -1955 \\
\hline & Difference (Tk.) & 3176 & 3569 & $-393\left(0.0276^{* *}\right)$ \\
\hline \multirow{3}{*}{ Farm income } & Before (Tk.) & 82484 & 83539 & -1055 \\
\hline & After (Tk.) & 88437 & 88755 & -318 \\
\hline & Difference (Tk.) & 5953 & 5216 & $737(0.9100)$ \\
\hline \multirow{3}{*}{ Non-farm income } & Before (Tk.) & 38775 & 38573 & 202 \\
\hline & After (Tk.) & 41846 & 40655 & 1191 \\
\hline & Difference (Tk.) & 3071 & 2082 & $989(0.1378)$ \\
\hline \multirow{3}{*}{ Total income } & Before (Tk.) & 121259 & 122112 & -853 \\
\hline & After (Tk.) & 130283 & 129410 & 873 \\
\hline & Difference (Tk.) & 9024 & 7298 & $1726(0.0748 *)$ \\
\hline \multirow{3}{*}{ Total expenditure } & Before (Tk.) & 112451 & 113168 & -717 \\
\hline & After (Tk.) & 115794 & 116737 & -943 \\
\hline & Difference (Tk.) & 3343 & 3569 & $-226\left(0.0090^{* * *}\right)$ \\
\hline
\end{tabular}

Source: Authors' estimation, 2015-16.

Note: Figures within the parentheses indicate p-value. $* * *, * *$ and $*$ indicate significant at 1,5 and 10 percent level. 


\section{Ravallion test result}

The comparison of average annual income and expenditure among the groups of farmers is estimated by Ravallion test which is represented in table 9. Average annual farm income, non-farm income and total income of focal farmers after adopting conservation agriculture practice were increased by Tk. 1508, Tk. 311 and Tk. 1819, respectively compared to proximal farmers; and by Tk. 1190, Tk. 1502 and Tk. 2692, respectively compared to control farmers. In case of proximal farmers, average annual non-farm income and total income were increased by Tk. 1191 and Tk. 873, respectively in comparison with control farmers but average annual farm income was decreased by Tk. 318. It is also experienced that average annual expenditure of focal farmers compared to proximal and control farmers was decreased by Tk. 1012 and Tk. 1955, respectively where it was decreased by Tk. 943 in case of proximal farmers compared to control farmers. Most of the values were statistically significant indicating a positive and noteworthy improvement on income and expenditure of the farmers after adopting conservation agriculture practice in the study areas. The result is quite similar with Nguema et al. (2013) where the authors found that specific cover crops, crop rotations and reduced tillage designed to reduce soil erosion and increase soil organic matter led to increased incomes for farm households in a time period of two years.

Table 9. Ravallion test result to compare average annual income and expenditure of the farmers

(in Tk.)

\begin{tabular}{l|c|c|c|c|c}
\hline \multicolumn{5}{c}{ For focal and proximal farmers } \\
\hline \multirow{2}{*}{ Particulars } & \multicolumn{5}{c}{ Farmer' category } \\
\cline { 2 - 6 } & Focal & Proximal & Change & t-value & p-value \\
\hline Farm income & 89945 & 88437 & 1508 & 2.96 & $0.0031^{* * *}$ \\
Non-farm income & 42157 & 41846 & 311 & 1.82 & $0.0867 *$ \\
Total income & 132102 & 130283 & 1819 & 0.16 & 0.6930 \\
Total expenditure & 114782 & 115794 & -1012 & 2.36 & $0.0484^{* *}$ \\
Farm income & 89945 & 88755 & 1190 & 1.69 & $0.0632^{*}$ \\
Non-farm income & 42157 & 40655 & 1502 & 1.25 & 0.5317 \\
Total income & 132102 & 129410 & 2692 & 2.13 & $0.0322^{* *}$ \\
Total expenditure & 114782 & 116737 & -1955 & 1.42 & 0.3983 \\
Farm income & 88437 & 88755 & -318 & 0.14 & 0.4219 \\
Non-farm income & 41846 & 40655 & 1191 & 1.30 & 0.2580 \\
Total income & 130283 & 129410 & 873 & 1.95 & $0.0833 *$ \\
Total expenditure & 115794 & 116737 & -943 & 1.79 & $0.0904 *$ \\
\hline
\end{tabular}

Source: Authors' estimation, 2015-16.

Note: $* * *, * *$ and $*$ indicate significant at 1,5 and 10 percent level. 


\section{Expenditure elasticity}

Expenditure elasticity is measured as proportional change in expenditure with respect to proportional change in income, remaining other factors constant. Table 10 expresses that expenditure elasticity of focal, proximal and control farmers was 0.31 , 0.44 and 0.58 percent, respectively; which means that with 1 percent increase in income, expenditure of focal, proximal and control farmers were increased by 0.31 , 0.44 and 0.58 percent, respectively when other internal and external factors held constant. The result implies that if the farmers of the study areas could increase their money income by Tk. 100, the expenditure would be increased by Tk. 31, Tk. 44 and Tk. 58 in stare of focal, proximal and control farmers, respectively after adopting conservation agriculture practice, keeping other influencing factors the same.

Table 10. Estimation of expenditure elasticity

\begin{tabular}{l|c|c|c|c|c|c|c}
\hline \multirow{2}{*}{$\begin{array}{l}\text { Farmers } \\
\text { categories }\end{array}$} & \multicolumn{3}{|c|}{ Income (Tk.) } & \multicolumn{3}{c|}{ Expenditure (Tk.) } & \multirow{2}{*}{$\begin{array}{c}\text { Expenditure } \\
\text { elasticity (\%) }\end{array}$} \\
\cline { 2 - 7 } & Before & After & Change & Before & After & Change & \\
\hline Focal & 120544 & 132101 & 11558 & 111606 & 114782 & 3175 & 0.31 \\
Proximal & 121259 & 130283 & 9024 & 112451 & 115794 & 3343 & 0.44 \\
Control & 122113 & 129211 & 7099 & 113168 & 116737 & 3569 & 0.58 \\
\hline
\end{tabular}

Source: Authors' estimation, 2015-16.

\section{Multidimensional poverty index (MPI)}

Poverty situation and livelihood condition of the farm households are evaluated on the basis of three poverty dimensions: health (weighted indicators: nutrition and child mortality), education (weighted indicators: years of schooling and child enrolment) and living standards (weighted indicators: cooking fuel, sanitation, water, electricity, floor and assets). It is found from tables 11, 12 and 13 that the percentage of deprived focal, proximal and control households was 21.7, 32.8 and 45.1 percent, respectively; and the percentage of privileged focal, proximal and control households was 78.3, 67.2 and 54.9 percent, respectively. The households were deprived or privileged of all the indicators of a single dimension or at a combination of the indicators across dimensions. The reason for a better livelihood condition of focal farmers by practicing conservation agriculture was that farmers employed their saved labour in other works and earned extra money income. Also, money saved from reduced use of synthetic fertilizers and pesticides were used in other livelihood activities. Crops free of synthetic fertilizers and pesticides as well as organic crops had a huge demand in the market and accordingly the farmers earned a notable amount of money by selling these products. This result is quite similar with Tshuma et al. (2012) where the authors found that conservation agriculture practice extended the range of livelihood on a limited scale through improved yields and income. 
Table 11. Multidimensional poverty index (MPI) for focal farmers

\begin{tabular}{|c|c|c|c|c|c|c|c|c|c|c|c|}
\hline \multirow{6}{*}{ Indicators } & \multicolumn{10}{|c|}{ Study areas } & \multirow{6}{*}{ Weights } \\
\hline & \multicolumn{2}{|c|}{ Mymensingh } & \multicolumn{2}{|c|}{ Bogra } & \multicolumn{2}{|c|}{ Tangail } & \multicolumn{2}{|c|}{ Sherpur } & \multicolumn{2}{|c|}{ Jamalpur } & \\
\hline & \multicolumn{10}{|c|}{ Average household size } & \\
\hline & \multicolumn{2}{|c|}{$\begin{array}{c}6 \\
(\mathrm{~N}=10)\end{array}$} & \multicolumn{2}{|c|}{$\begin{array}{c}5 \\
(\mathrm{~N}=10)\end{array}$} & \multicolumn{2}{|c|}{$\begin{array}{c}5 \\
(\mathrm{~N}=10)\end{array}$} & \multicolumn{2}{|c|}{$\begin{array}{c}6 \\
(\mathrm{~N}=10)\end{array}$} & \multicolumn{2}{|c|}{$\begin{array}{c}7 \\
(\mathrm{~N}=10)\end{array}$} & \\
\hline & \multicolumn{10}{|c|}{ No. of households deprived $(\sqrt{ })$ or privileged $(\times)$ of the indicators } & \\
\hline & $\sqrt{ }$ & $x$ & $\sqrt{ }$ & $x$ & $\sqrt{ }$ & $x$ & $\sqrt{ }$ & $x$ & $\sqrt{ }$ & $x$ & \\
\hline \multicolumn{12}{|c|}{ Education } \\
\hline $\begin{array}{l}\text { No one has completed } \\
\text { five years of schooling }\end{array}$ & $6 / 10$ & $4 / 10$ & $3 / 10$ & $7 / 10$ & $4 / 10$ & $6 / 10$ & $2 / 10$ & $8 / 10$ & $4 / 10$ & $6 / 10$ & $1 / 6$ \\
\hline $\begin{array}{l}\text { At least one school-age } \\
\text { child not enrolled in } \\
\text { school }\end{array}$ & $0 / 10$ & $10 / 10$ & $1 / 10$ & $9 / 10$ & $1 / 10$ & $9 / 10$ & $0 / 10$ & $10 / 10$ & $0 / 10$ & $10 / 10$ & $1 / 6$ \\
\hline \multicolumn{12}{|c|}{ Health } \\
\hline $\begin{array}{l}\text { At least one member is } \\
\text { malnourished }\end{array}$ & $0 / 10$ & $10 / 10$ & $2 / 10$ & $8 / 10$ & $0 / 10$ & $10 / 10$ & $0 / 10$ & $10 / 10$ & $0 / 10$ & $10 / 10$ & $1 / 6$ \\
\hline $\begin{array}{l}\text { One or more children } \\
\text { have died }\end{array}$ & $2 / 10$ & $8 / 10$ & $0 / 10$ & $10 / 10$ & $0 / 10$ & $10 / 10$ & $0 / 10$ & $10 / 10$ & $1 / 10$ & $9 / 10$ & $1 / 6$ \\
\hline \multicolumn{12}{|c|}{ Living standards } \\
\hline No electricity & $0 / 10$ & $10 / 10$ & $0 / 10$ & $10 / 10$ & $1 / 10$ & $9 / 10$ & $3 / 10$ & $7 / 10$ & $0 / 10$ & $10 / 10$ & $1 / 18$ \\
\hline $\begin{array}{l}\text { No access to clean } \\
\text { drinking water }\end{array}$ & $0 / 10$ & $10 / 10$ & $0 / 10$ & $10 / 10$ & $0 / 10$ & $10 / 10$ & $0 / 10$ & $10 / 10$ & $0 / 10$ & $10 / 10$ & $1 / 18$ \\
\hline $\begin{array}{l}\text { No access to adequate } \\
\text { sanitation }\end{array}$ & $2 / 10$ & $8 / 10$ & $3 / 10$ & $7 / 10$ & $3 / 10$ & $7 / 10$ & $2 / 10$ & $8 / 10$ & $2 / 10$ & $8 / 10$ & $1 / 18$ \\
\hline House has dirt floor & $1 / 10$ & $9 / 10$ & $0 / 10$ & $10 / 10$ & $0 / 10$ & $10 / 10$ & $0 / 10$ & $10 / 10$ & $1 / 10$ & $9 / 10$ & $1 / 18$ \\
\hline $\begin{array}{l}\text { Household uses 'dirty' } \\
\text { cooking fuel (dung, } \\
\text { firewood or charcoal) }\end{array}$ & $10 / 10$ & $0 / 10$ & $10 / 10$ & $0 / 10$ & $10 / 10$ & $0 / 10$ & $10 / 10$ & $0 / 10$ & $10 / 10$ & $0 / 10$ & $1 / 18$ \\
\hline $\begin{array}{l}\text { Household has no car } \\
\text { and owns at most one } \\
\text { bicycle, motorcycle, } \\
\text { radio, refrigerator, } \\
\text { telephone or television }\end{array}$ & $10 / 10$ & $0 / 10$ & $10 / 10$ & $0 / 10$ & $10 / 10$ & $0 / 10$ & $10 / 10$ & $0 / 10$ & $10 / 10$ & $0 / 10$ & $1 / 18$ \\
\hline Score of the households & 0.261 & 0.739 & 0.228 & 0.772 & 0.217 & 0.783 & 0.172 & 0.828 & 0.211 & 0.789 & - \\
\hline \multirow{2}{*}{ Intensity of poverty (\%) } & \multicolumn{6}{|c|}{ Deprived households } & \multicolumn{5}{|c|}{ Privileged households } \\
\hline & \multicolumn{6}{|c|}{21.7} & \multicolumn{5}{|c|}{78.3} \\
\hline
\end{tabular}

Source: Authors' estimation, 2015-16.

Note: Score of deprived households in Mymensingh district $=(6 / 10 \times 1 / 6)+(0 / 10 \times 1 / 6)+(0 / 10 \times 1 / 6)+(2 / 10 \times$ $1 / 6)+(0 / 10 \times 1 / 18)+(0 / 10 \times 1 / 18)+(2 / 10 \times 1 / 18)+(1 / 10 \times 1 / 18)+(10 / 10 \times 1 / 18)+(10 / 10 \times 1 / 18)=0.261$

Score of privileged households in Mymensingh district $=(4 / 10 \times 1 / 6)+(10 / 10 \times 1 / 6)+(10 / 10 \times 1 / 6)+(8 / 10 \times 1 / 6)$ $+(10 / 10 \times 1 / 18)+(10 / 10 \times 1 / 18)+(8 / 10 \times 1 / 18)+(9 / 10 \times 1 / 18)+(0 / 10 \times 1 / 18)+(0 / 10 \times 1 / 18)=0.739$

Score of deprived or privileged households of other districts is calculated accordingly.

Deprived households $(\%)=[\{(0.261 \times 6)+(0.228 \times 5)+(0.217 \times 5)+(0.172 \times 6)+(0.211 \times 7)\} \div(6+5+5+6+$ 7) $] \times 100=21.7 \%$

Privileged households $(\%)=[\{(0.739 \times 6)+(0.772 \times 5)+(0.783 \times 5)+(0.828 \times 6)+(0.789 \times 7)\} \div(6+5+5+6+$ 7) $] \times 100=78.3 \%$ 
Table 12. Multidimensional poverty index (MPI) for proximal farmers

\begin{tabular}{|c|c|c|c|c|c|c|c|c|c|c|c|}
\hline \multirow{6}{*}{ Indicators } & \multicolumn{10}{|c|}{ Study areas } & \multirow{6}{*}{ Weights } \\
\hline & \multicolumn{2}{|c|}{ Mymensingh } & \multicolumn{2}{|c|}{ Bogra } & \multicolumn{2}{|c|}{ Tangail } & \multicolumn{2}{|c|}{ Sherpur } & \multicolumn{2}{|c|}{ Jamalpur } & \\
\hline & \multicolumn{10}{|c|}{ Average household size } & \\
\hline & \multicolumn{2}{|c|}{$\begin{array}{c}6 \\
(\mathrm{~N}=20)\end{array}$} & \multicolumn{2}{|c|}{$\begin{array}{c}6 \\
(\mathrm{~N}=20)\end{array}$} & \multicolumn{2}{|c|}{$\begin{array}{c}4 \\
(\mathrm{~N}=20)\end{array}$} & \multicolumn{2}{|c|}{$\begin{array}{c}5 \\
(\mathrm{~N}=20)\end{array}$} & \multicolumn{2}{|c|}{$\begin{array}{c}5 \\
(\mathrm{~N}=20)\end{array}$} & \\
\hline & \multicolumn{10}{|c|}{ No. of households deprived $(\sqrt{ })$ or privileged $(\times)$ of the indicators } & \\
\hline & $\sqrt{ }$ & $x$ & $\sqrt{ }$ & $x$ & $\sqrt{ }$ & $x$ & $\sqrt{ }$ & $x$ & $\sqrt{ }$ & $x$ & \\
\hline \multicolumn{12}{|c|}{ Education } \\
\hline $\begin{array}{l}\text { No one has completed } \\
\text { five years of schooling }\end{array}$ & $\begin{array}{c}12 / 2 \\
0\end{array}$ & $8 / 20$ & $12 / 20$ & $8 / 20$ & $\begin{array}{c}13 / 2 \\
0\end{array}$ & $7 / 20$ & $12 / 20$ & $8 / 20$ & $13 / 20$ & $7 / 20$ & $1 / 6$ \\
\hline $\begin{array}{l}\text { At least one school-age } \\
\text { child not enrolled in } \\
\text { school }\end{array}$ & $6 / 20$ & $14 / 20$ & $6 / 20$ & $14 / 20$ & $7 / 20$ & $13 / 20$ & $8 / 20$ & $12 / 20$ & $7 / 20$ & $13 / 20$ & $1 / 6$ \\
\hline \multicolumn{12}{|c|}{ Health } \\
\hline $\begin{array}{l}\text { At least one member is } \\
\text { malnourished }\end{array}$ & $4 / 20$ & $16 / 20$ & $4 / 20$ & $16 / 20$ & $3 / 20$ & $17 / 20$ & $4 / 20$ & $16 / 20$ & $4 / 20$ & $16 / 20$ & $1 / 6$ \\
\hline $\begin{array}{l}\text { One or more children } \\
\text { have died }\end{array}$ & $0 / 20$ & $20 / 20$ & $0 / 20$ & $20 / 20$ & $0 / 20$ & $20 / 20$ & $0 / 20$ & $20 / 20$ & $0 / 20$ & $20 / 20$ & $1 / 6$ \\
\hline \multicolumn{12}{|c|}{ Living standards } \\
\hline No electricity & $2 / 20$ & $18 / 20$ & $2 / 20$ & $18 / 20$ & $2 / 20$ & $18 / 20$ & $4 / 20$ & $16 / 20$ & $3 / 20$ & $17 / 20$ & $1 / 18$ \\
\hline $\begin{array}{l}\text { No access to clean } \\
\text { drinking water }\end{array}$ & $0 / 20$ & $20 / 20$ & $0 / 20$ & $20 / 20$ & $0 / 20$ & $20 / 20$ & $0 / 20$ & $20 / 20$ & $0 / 20$ & $20 / 20$ & $1 / 18$ \\
\hline $\begin{array}{l}\text { No access to adequate } \\
\text { sanitation }\end{array}$ & $4 / 20$ & $16 / 20$ & $3 / 20$ & $17 / 20$ & $3 / 20$ & $17 / 20$ & $4 / 20$ & $16 / 20$ & $5 / 20$ & $15 / 20$ & $1 / 18$ \\
\hline House has dirt floor & $3 / 20$ & $17 / 20$ & $2 / 20$ & $18 / 20$ & $4 / 20$ & $16 / 20$ & $2 / 20$ & $18 / 20$ & $3 / 20$ & $17 / 20$ & $1 / 18$ \\
\hline $\begin{array}{l}\text { Household uses 'dirty' } \\
\text { cooking fuel (dung, } \\
\text { firewood or charcoal) }\end{array}$ & $\begin{array}{c}20 / 2 \\
0\end{array}$ & $0 / 20$ & $20 / 20$ & $0 / 20$ & $20 / 20$ & $0 / 20$ & $20 / 20$ & $0 / 20$ & $20 / 20$ & $0 / 20$ & $1 / 18$ \\
\hline $\begin{array}{l}\text { Household has no car } \\
\text { and owns at most one } \\
\text { bicycle, motorcycle, } \\
\text { radio, refrigerator, } \\
\text { telephone or television }\end{array}$ & $\begin{array}{c}20 / 2 \\
0\end{array}$ & $0 / 20$ & $20 / 20$ & $0 / 20$ & $20 / 20$ & $0 / 20$ & $20 / 20$ & $0 / 20$ & $20 / 20$ & $0 / 20$ & $1 / 18$ \\
\hline Score of the households & $\begin{array}{c}0.32 \\
0\end{array}$ & 0.680 & 0.315 & 0.685 & 0.331 & 0.669 & 0.340 & 0.660 & 0.341 & 0.659 & - \\
\hline Intensity of poverty & \multicolumn{6}{|c|}{ Deprived households } & \multicolumn{5}{|c|}{ Privileged households } \\
\hline$(\%)$ & \multicolumn{6}{|c|}{32.8} & \multicolumn{5}{|c|}{67.2} \\
\hline
\end{tabular}

Source: Authors' estimation, 2015-16. 
Table 13. Multidimensional poverty index (MPI) for control farmers

\begin{tabular}{|c|c|c|c|c|c|c|c|c|c|c|c|}
\hline \multirow{6}{*}{ Indicators } & \multicolumn{10}{|c|}{ Study areas } & \multirow{6}{*}{ Weights } \\
\hline & \multicolumn{2}{|c|}{ Mymensingh } & \multicolumn{2}{|c|}{ Bogra } & \multicolumn{2}{|c|}{ Tangail } & \multicolumn{2}{|c|}{ Sherpur } & \multicolumn{2}{|c|}{ Jamalpur } & \\
\hline & \multicolumn{10}{|c|}{ Average household size } & \\
\hline & \multicolumn{2}{|c|}{$\begin{array}{c}5 \\
(\mathrm{~N}=30)\end{array}$} & \multicolumn{2}{|c|}{$\begin{array}{c}7 \\
(\mathrm{~N}=30)\end{array}$} & \multicolumn{2}{|c|}{$\begin{array}{c}6 \\
(\mathrm{~N}=30)\end{array}$} & \multicolumn{2}{|c|}{$\begin{array}{c}6 \\
(\mathrm{~N}=30)\end{array}$} & \multicolumn{2}{|c|}{$\begin{array}{c}4 \\
(\mathrm{~N}=30)\end{array}$} & \\
\hline & \multicolumn{10}{|c|}{ No. of households deprived $(\sqrt{ })$ or privileged $(\times)$ of the indicators } & \\
\hline & $\sqrt{ }$ & $x$ & $\sqrt{ }$ & $x$ & $\sqrt{ }$ & $x$ & $\sqrt{ }$ & $x$ & $\sqrt{ }$ & $x$ & \\
\hline \multicolumn{12}{|c|}{ Education } \\
\hline $\begin{array}{l}\text { No one has completed } \\
\text { five years of schooling }\end{array}$ & $22 / 30$ & $8 / 30$ & $19 / 30$ & $11 / 30$ & $22 / 30$ & $8 / 30$ & $20 / 30$ & $10 / 30$ & $21 / 30$ & $9 / 30$ & $1 / 6$ \\
\hline $\begin{array}{l}\text { At least one school-age } \\
\text { child not enrolled in } \\
\text { school }\end{array}$ & $19 / 30$ & $11 / 30$ & $16 / 30$ & $14 / 30$ & $18 / 30$ & $12 / 30$ & $19 / 30$ & $11 / 30$ & $17 / 30$ & $13 / 30$ & $1 / 6$ \\
\hline \multicolumn{12}{|c|}{ Health } \\
\hline $\begin{array}{l}\text { At least one member is } \\
\text { malnourished }\end{array}$ & $11 / 30$ & $19 / 30$ & $16 / 30$ & $14 / 30$ & $13 / 30$ & $17 / 30$ & $11 / 30$ & $19 / 30$ & $15 / 30$ & $15 / 30$ & $1 / 6$ \\
\hline $\begin{array}{l}\text { One or more children } \\
\text { have died }\end{array}$ & $0 / 30$ & $30 / 30$ & $0 / 30$ & $30 / 30$ & $0 / 30$ & $30 / 30$ & $0 / 30$ & $30 / 30$ & $0 / 30$ & $30 / 30$ & $1 / 6$ \\
\hline \multicolumn{12}{|c|}{ Living standards } \\
\hline No electricity & $8 / 30$ & $22 / 30$ & $7 / 30$ & $23 / 30$ & $10 / 30$ & $20 / 30$ & $10 / 30$ & $20 / 30$ & $8 / 30$ & $22 / 30$ & $1 / 18$ \\
\hline $\begin{array}{l}\text { No access to clean } \\
\text { drinking water }\end{array}$ & $2 / 30$ & $28 / 30$ & $2 / 30$ & $28 / 30$ & $0 / 30$ & $30 / 30$ & $4 / 30$ & $26 / 30$ & $3 / 30$ & $27 / 30$ & $1 / 18$ \\
\hline $\begin{array}{l}\text { No access to adequate } \\
\text { sanitation }\end{array}$ & $4 / 30$ & $26 / 30$ & $6 / 30$ & $24 / 30$ & $6 / 30$ & $24 / 30$ & $5 / 30$ & $25 / 30$ & $7 / 30$ & $23 / 30$ & $1 / 18$ \\
\hline House has dirt floor & $12 / 30$ & $18 / 30$ & $13 / 30$ & $17 / 30$ & $10 / 30$ & $20 / 30$ & $12 / 30$ & $18 / 30$ & $11 / 30$ & $19 / 30$ & $1 / 18$ \\
\hline $\begin{array}{l}\text { Household uses 'dirty' } \\
\text { cooking fuel (dung, } \\
\text { firewood or charcoal) }\end{array}$ & $30 / 30$ & $0 / 30$ & $30 / 30$ & $0 / 30$ & $30 / 30$ & $0 / 30$ & $30 / 30$ & $0 / 30$ & $30 / 30$ & $0 / 30$ & $1 / 18$ \\
\hline $\begin{array}{l}\text { Household has no car } \\
\text { and owns at most one } \\
\text { bicycle, motorcycle, } \\
\text { radio, refrigerator, } \\
\text { telephone or television }\end{array}$ & $30 / 30$ & $0 / 30$ & $30 / 30$ & $0 / 30$ & $30 / 30$ & $0 / 30$ & $30 / 30$ & $0 / 30$ & $30 / 30$ & $0 / 30$ & $1 / 18$ \\
\hline Score of the households & 0.449 & 0.551 & 0.448 & 0.552 & 0.455 & 0.545 & 0.447 & 0.553 & 0.460 & 0.540 & - \\
\hline \multirow{2}{*}{ Intensity of poverty (\%) } & \multicolumn{6}{|c|}{ Deprived households } & \multicolumn{5}{|c|}{ Privileged households } \\
\hline & \multicolumn{6}{|c|}{45.1} & \multicolumn{5}{|c|}{54.9} \\
\hline
\end{tabular}

Source: Authors' estimation, 2015-16.

\section{CONCLUSIONS AND POLICY RECOMMENDATIONS}

The study concludes that conservation agriculture as a new resource saving farming practice was appreciated and successfully adopted by the farmers. Farmers had been given knowledge and training on different aspects of conservation 
agriculture practice. It is also found that cost of crop production was relatively lower and return from production was comparatively higher in conservation agriculture practice than conventional agriculture practice. It is also revealed that farmers' income was increased and expenditure was decreased through adopting conservation agriculture practice. Farmers got higher price for their product free from poisonous medicine and synthetic fertilizers. This practice helped the farmers to minimize their labour and other input cost. The study also indicates that poverty in terms of deprivation of health, education and living standards was decreased; and overall livelihood circumstances was improved adopting conservation agriculture practice. Considering the findings of the study, some essential policy recommendations have been arisen which are: input support, motivation and extension services of government should be properly implemented to raise the awareness about practicing conservation agriculture and its importance on crop production. Also, initiative for scientific and technical training programmes should be arranged by different government and non-government organizations to enrich the knowledge of the farmers on conservation agriculture practice.

\section{REFERENCES}

Akter, S. and Gathala, M. K. 2014. Adoption of conservation agriculture technology in diversified systems and impact on productivity: Evidence from three districts in Bangladesh. In $88^{\text {th }}$ annual conference of the Agricultural Economics Society, Paris, France

Akteruzzaman, M., Jahan, H. and Haque, M. D. 2012. Practices of conservation agricultural technologies in diverse cropping systems in Bangladesh. Bangladesh Journal of Agricultural Economics, 35 (1 \& 2): 143-144

BBS, 2014. Statistical Yearbook of Bangladesh, Bangladesh Bureau of Statistics, Statistics Division, Ministry of Planning, Government of the People's Republic of Bangladesh, Dhaka

Browne, M., Ortmann, G. F. and Hendriks, S. 2007. Expenditure elasticities for rural households in the Embo Ward, Umbumbulu, KwaZulu-Natal. Agrekon, 46 (4): 567568

Dhaliwal, H. S. and Singh, J. 2004. Socio-economic impact of zero-tillage technology in wheat in Punjab. Centre for Advancement of Sustainable Agriculture, National Agriculture Science Centre, New Delhi, India

FAO, 2007. Food and Agriculture Organization of the United Nations

HDR, 2015. Human Development Report, Work for Human Development, United Nations Development Programme, New York, United States of America

IFAD, 2005. International Fund for Agricultural Development

Kafiluddin, A. and Islam, M. S. 2008. Fertilizer distribution, subsidy, marketing, promotion and agronomic use efficiency scenario in Bangladesh. In IFA Crossroads Asia-Pacific 2008, Melbourne, Australia 
Kumar, S., Sharma, K. L., Kareemulla, K., Chary, G. R., Ramarao, C. A., Rao, C. S. and Venkateswarlu, B. 2011. Techno-economic feasibility of conservation agriculture in rainfed regions of India. Current Science, 101 (9): 1171-1181

Lai, C., Chan, C., Halbrendt, J., Shariq, L., Roul, P., Idol, T., Ray, C. and Evensen, C. 2012. Comparative economic and gender, labor analysis of conservation agriculture practices in tribal villages in India. International Food and Agribusiness Management Review, 15 (1): $73-86$

Lampkin, N. H. and Padel, S. 1994. The economics of organic farming: An international perspective. Cab International, Oxon, UK

Nguema, A., Norton, G. W., Alwang, J., Taylor, D. B., Barrera, V. and Bertelsen, M. 2013. Farm-level economic impacts of conservation agriculture in Ecuador. Experimental Agriculture, 49 (1): 134-147

Nkala, P. 2012. Assessing the impacts of conservation agriculture on farmer livelihoods in three selected communities in Central Mozambique. Ph.D. Thesis, University of Natural Resources and Life Sciences, Vienna, Austria

Parrott, N., Olesen, J. E. and Hogh-Jensen, H. 2006. Certified and non-certified organic farming in the developing world. p. 153-176. Global development of organic agriculture: Challenges and prospects. CAB International, Wallingford, Oxon.

Rahman, M. H. 2001. The Influence of extension on the introduction of organic farming in Bangladesh. Litverlag Münster, Hamburg, London

Ravallion, M. 2008. Evaluating anti-poverty programs. Handbook of Development Economics, 4 (5): 3787-3846

Tshuma, N., Maphosa, M., Ncube, G., Dube, T. and Dube, Z. L. 2012. The Impact of conservation agriculture on food security and livelihoods in Mangwe district. Journal of Sustainable Development in Africa, 14 (5): 107-125

Willer, H., Yussefi, M., Menzler and Sorensen, N. 2008. The world of organic agriculture statistics and emerging trends 2008, main results. The World of Organic Agriculture, Bonn 